- Washington DC. Ghosh came to the United States from India in 2003 for a postdoctoral fellowship at the National Cancer Institute in Bethesda, Maryland, and finished a second fellowship at Howard University in 2007. He applied for permanent residency in December 2010 and was approved in 2011, but he has yet to receive his green card.

Ghosh also wants to travel abroad, but, without a green card, he could encounter administrative delays when he tries to re-enter the United States. Last year, he turned down an invitation to speak at a conference in France.

Worries about conference travel are a big problem for many postdoctoral fellows on temporary visas, says Benjamin Corb, director of public affairs at the American Society for Biochemistry and Molecular Biology in Rockville,

Maryland. “They just don't go, so they lose out on that opportunity in their professional career," he says. That understandable caution can also exact heavy personal costs. Ghosh was too afraid to return to India to see his sister before she died of cancer in January.

Ghosh's visa, unlike

\section{"Our system is absolutely, utterly broken."} a green card, does not allow him to change jobs easily. He would like to move into the field of medical diagnostics and eventually start his own company. "I'm 45 now," he says. "I want to start my own career."

Hopes of clearing the green card logjam now rest with the Republican-controlled House of Representatives, and its leaders are preparing separate proposals to address immigration.
Although increased immigration for scientists and engineers enjoys broad bipartisan support, Republicans argue that STEM green cards should be created only at the expense of other categories, such as the annual green card lottery for natives of countries that send few immigrants to the United States. But Democrats, who control the Senate, reject that notion. Any changes to the visa system will require agreement by both sides on a broader suite of hotly contested immigration issues.

For Basu, the stakes may be higher than for most. He and his wife are expecting their first child in three weeks, and he worries that the family may ultimately have to move back to India - away from the life they have created in Virginia. "Our kid will be an American citizen," says Basu. "We have roots here." -

\title{
European deal cuts red tape
}

\section{Horizon 2020 research programme streamlines project reimbursements.}

\section{BY QUIRIN SCHIERMEIER}

A deal struck last week during negotiations on the research programme for the next seven years in the European Union (EU) promises a significant change to the way in which institutions are reimbursed for the overhead costs of their research. The agreement for Horizon 2020 sweeps away the onerous red tape involved in the present diverse arrangements and replaces it with an acrossthe-board 25\% reimbursement rate for all.

Although the deal could be a boon for the many European universities with low overheads, which include heating, lighting, rent and facilities maintenance, it has disappointed some operators of large research facilities, mainly those in Western Europe. They warn that the simplified funding rules could harm top-ranking centres with high overheads because they will need reimbursement beyond $25 \%$ of the total direct costs.

"The new rules threaten to make Horizon 2020 extremely unattractive, particularly for research organizations dedicated to innovation," says Reimund Neugebauer, president of the Fraunhofer Society, headquartered in Munich, Germany, which carries out contract research for industry.

Details of Horizon 2020, due to start next January, have been under negotiation since February in a series of talks between EU member

\section{ONATURE.COM} Complex accounting rules cost the EU millions: go.nature.com/nc69zw

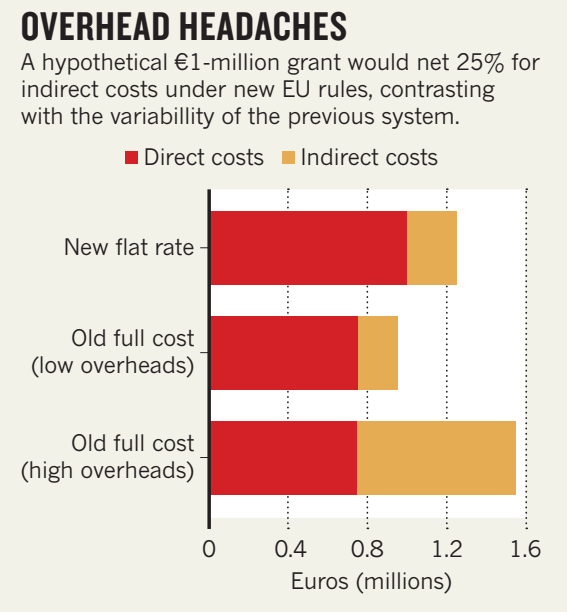

states, the European Parliament and the European Commission. The three were united on the programme's goal to spur economic growth and on its broad themes, which include health and energy research. But the parliament and member states have been squabbling over what accounting rules might best serve Europe's paperwork-plagued research community. The United States, too, has stumbled over funding of indirect costs (see 'Transatlantic concerns'), but some had feared that the European deadlock over the issue would delay the start of Horizon 2020.

Keen to simplify the affair, the European Commission and most member states threw their support behind a system that would pay grant-winners the full direct costs of a project, such as salaries, travel and laboratory supplies, plus a $25 \%$ flat rate to cover overheads. Such a move would also please the EU's auditors - in a report released on 7 June, they slammed the complex funding model used in the organization's 2007-13 research programme.

But some Members of the European Parliament (MEPs) - backed by the European University Association in Brussels, which represents many of Europe's universities and research institutes - held that such an approach would make participation in Horizon 2020 unattractive for institutions with high overheads. Universities that run expensive facilities, for example ocean-going research vessels and synchrotron machines, would be left out of pocket, as would organizations such as the Fraunhofer, which have high overheads because the contract research they carry out often involves the use of expensive industryowned research facilities.

Critics of the flat rate were pushing for the 'full cost' reimbursement model used in the last EU research programme. This would have allowed organizations to get $75 \%$ of their direct costs plus $100 \%$ of their indirect costs which can sometimes be as high as the direct costs (see 'Overhead headaches'). In the end, a majority of member states and the commission gained the upper hand in their attempt to simplify the accounting. At the meeting last week, MEPs reluctantly agreed that Horizon 2020 would use only the flat-rate model. The deal must still be formally approved by 


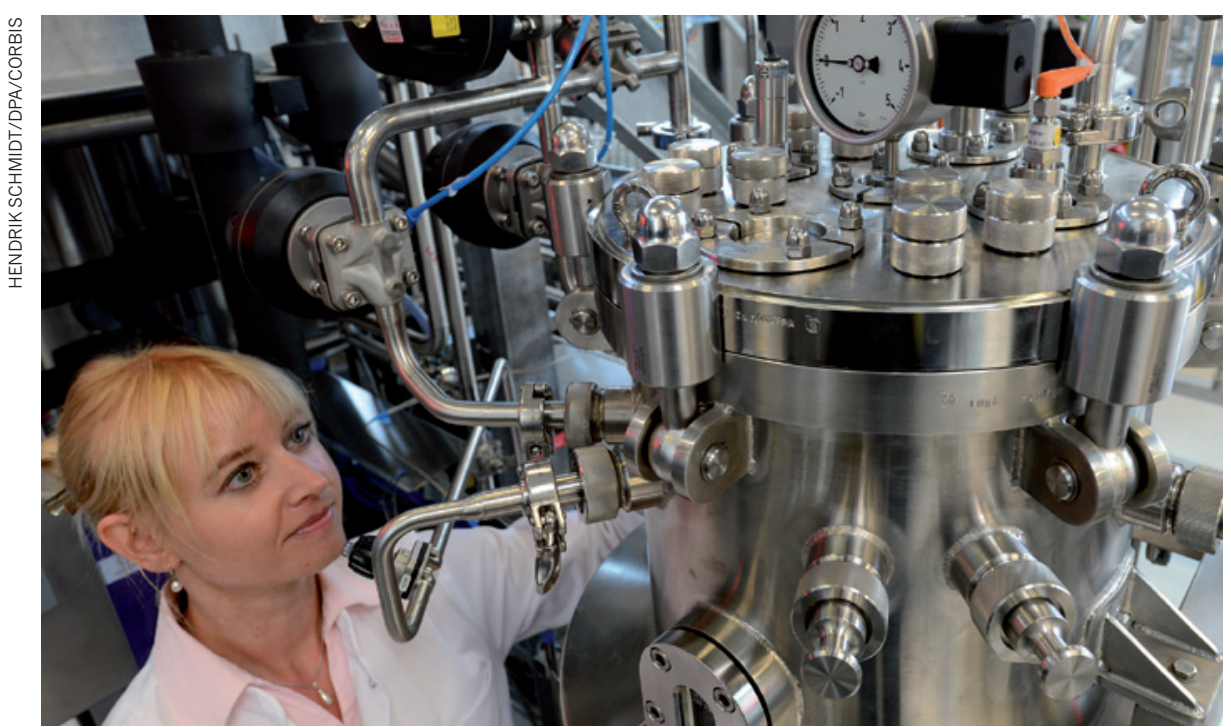

Research carried out by Germany's Fraunhofer Society might be hampered by European funding rules.

parliament and EU member states, but it is expected to pave the way for Horizon 2020 to start on schedule.

"The parliament managed to safeguard many improvements and substantial simplification for participants," said Christian Ehler, an MEP with the centre-right European People's Party and parliament's lead negotiator for Horizon 2020 , in a statement to Nature. "But I dread the fact that the parliament had to consent to the council's funding model" because it will dramatically disadvantage some institutions.

Nonetheless, some of Europe's elite research universities are pleased with the promised reduction in red tape. "Having one rule for all is a major improvement," says Kurt Deketelaere, secretary-general of the League of European Research Universities, a partnership of 21 top universities. "Imagine the insane complexity in collaborating with research organizations

\section{TRANSATLANTIC CONCERNS Flat rate overruled}

The thorny issue of overhead payments is not restricted to Europe. In the United States, the average reimbursement rate is around $50 \%$ of direct project costs, but top institutes such as Harvard University in Cambridge, Massachusetts, receive up to $70 \%$ of extra money from federal grants. Critics say that the current practice unfairly favours a few research powerhouses over many other, smaller universities. However, an attempt last year by President Barack Obama's administration to introduce a single flat rate met with fierce opposition from large institutes such as Harvard and the Massachusetts Institute of Technology in Cambridge. The plan was abandoned. Q.S. and companies which all follow different rules. That system had to go." By and large, says Deketelaere, universities will be better off financially than they were under previous EU research programmes.

But the commission has promised to address the concerns of those unhappy with the new rules. A recent commission working paper seen by Nature proposes that more of the costs incurred in operating research facilities could be reimbursed if the money were interpreted as being fully related to a Horizon 2020 project. "We will take the commission at its word," says Neugebauer.

Scientists in the 13 states that have joined the EU since 2004 could benefit from the changes thrashed out last week. Universities and institutes there have less experience in dealing with EU bureaucracy - a prerequisite for claiming and verifying overhead costs. Moreover, their overheads tend to be smaller than those of facilities-rich Western European research centres. As a further sweetener, scientists in these countries who receive a Horizon 2020 grant will get an annual salary bonus of $€ 8,000$ (US\$10,400).

The flat-rate system could also help scientists in such countries to win a bigger slice of EU funding, says Krzysztof Frackowiak, director of the Polish Science Contact Agency in Brussels, which helps Polish institutions to negotiate EU red tape. The newer member states "haven't been able to get back from Brussels nearly as much as they paid into European research programmes", he says.

\section{CORRECTION}

The $y$-axis in the graphic 'The rise of open access in the News Feature 'The true cost of science publishing' (Nature 495, 426-429; 2013) was mislabelled. The correct version is online at go.nature.com/e8rsrb. 